\title{
Hydroponic Cactus Pear Production, Productivity and Quality of Nopalito and Fodder
}

\author{
Hugo Magdaleno Ramírez-Tobías', Cristian López-Palacios², \\ Juan Rogelio Aguirre-Rivera ${ }^{3}$ and Juan Antonio Reyes-Agüero ${ }^{3, *}$ \\ ${ }^{1}$ Facultad de Agronomía, Universidad Autónoma de San Luis Potosí, San Luis Potosí \\ 2Posgrado en Botánica, Colegio de Postgraduados, Estado de México \\ ${ }^{3}$ Instituto de Investigación de Zonas Desérticas, \\ Universidad Autónoma de San Luis Potosí, San Luis Potosí \\ México
}

\section{Introduction}

The use of cactus pear for producing young cladodes (nopalitos) and fodder represent an attractive option to intensify plant production in arid and semi-arid regions. Nopalitos are considered functional food (Sáenz et al., 2004) and are used in Mexico since pre-Columbian times (Anaya, 2001). The adjective functional is due to additionally to the nutrient supplies, it provides health benefits and contributes to the prevention of some diseases (Sáenz et al., 2004) as is evidenced by results of investigations on the control of cholesterol and the prevention of some diseases like diabetes and obesity (Paiz et al., 2010; Sáenz, 2000). Nopalitos are served with meals, similar to green beans (Stintzing, 2005). Nopalitos of Opuntia are produced and consumed in temperate and dry regions while nopalitos of Nopalea genera are used in warm regions of Mexico (Sánchez-Venegas, 1995). Alternatively, fodder of cactus pear is significant in some regions of the world, mostly during the dry season of the year (Flores \& Aguirre, 1979; Gonzaga and Cordeiro, 2005). Fodder nutrient quality studies on Opuntia and Nopalea cladodes show variations among species, variants, growth stage of the sprouts and agronomic handling (López-García et al., 2001; Nefzaoui \& Ben Salem, 2001; Pinos-Rodríguez et al., 2006) and it has been stated that they have high carbohydrate and water content but have low nutrient and fiber content (López-García et al., 2001). Furthermore, nutritional potential of cactus pear to mitigate feed and water shortages in dry areas were demonstrated by Tegegnea et al. (2007).

Plant growth is a continuous process that strongly depends on genetic information and environmental conditions; and both, sprouting and growth of the cladodes of Opuntia and Nopalea occur independent on chronological time. Growth and development can modify some chemical characteristics of plants as those considered important for fodder and nopalito quality (Collins \& Frits, 2003; Rodríguez-Félix \& Cantwell, 1988). Nevertheless, several studies, as those of Cordeiro et al. (2000), Flores-Hernández et al. (2004), and Mondragón-Jacobo et al. (2001) evaluated the yield, the nutrimental value and quality of

${ }^{*}$ Corresponding Author 
cactus pear cladodes for fodder harvesting shoots on determinate fixed periods and it did not take account the shoot size or at least it did not specify this criteria. Then it is possible to infer that cutting cladodes considering fixed time periods would result in heterogeneous characteristics of shoots in quality and size at the harvest moment.

Cactus-pear productivity, as in other crops, is related to management practices. This is because plant productivity is an indicator of the cumulative effects of environmental factors that affect the growth (Nobel, 1988). Nutrient supply through the application of manure, fertilizer or both, coupled with irrigation, increases cladode production (Gonzaga \& Cordeiro, 2005). In fact, it has been showed that under optimal conditions, cactus pear productivity can be equal to or higher than that obtained with highly productive crops as corn, alfalfa, sorghum and other (Nobel, 1988). The most extreme of the best production conditions is hydroponics, which provides up to $450 \mathrm{t} \mathrm{ha}^{-1}$ of green fodder in six months (Mondragón-Jacobo et al., 2001). Hydroponics is an efficient system for the use of water (Sánchez \& Escalante, 1993), a scarce resource in arid regions. Moreover, from the point of view of experimentation, hydroponics provides a controlled environment which makes possible to reduce variance and to evaluate more precisely the reactions to diverse variation sources.

The aims of this work was to know the productivity and the changes of chemical characteristics as forage and nopalito quality of three Opuntia species and one Nopalea species, in a hydroponic system. The effects of maturity on studied characteristics were measured using fixed cladode sizes as harvest criterium and not a chronological criterium. As a consequence of size criterium for harvesting shoots, the harvest frequency was also studied. The information presented here is a summary of several works (López-Palacios, 2008; López-Palacios et al., 2010; Ramírez-Tobías, 2006; Ramírez-Tobías et al., 2007a, 2007b, 2010) that the authors have been developed in the last years. Moreover, comparisons of productivity and quality terms as nopalito and fodder against results obtain by production systems on soil are discussed.

\section{Materials and methods}

An experiment in a hydroponic system under a greenhouse was conducted in San José de la Peña, Villa de Guadalupe, San Luis Potosí, México (23 $15^{\prime} 00^{\prime \prime} \mathrm{NL}, 100^{\circ} 45^{\prime} 20^{\prime \prime} \mathrm{WL}$ and $1735 \mathrm{~m}$ asl). The greenhouse was an East-West linear tunnel. The climate in San José de la Peña is semiarid, with extreme daily temperatures oscillation and cold winters (García, 2004).

The greenhouse had no additional controls of temperature such as heaters or coolers; the greenhouse temperature was recorded with a hygrothermograph, which averaged a yearly $22{ }^{\circ} \mathrm{C}$ temperature with an annual variation of $8^{\circ} \mathrm{C}$. The hydroponic system were four bench containers made with fluted fiberglass, measuring 1.80 long, 1.20 wide and $0.30 \mathrm{~m}$ high. Tezontle, a red volcanic grave, was used as substrate for the cactus pear plants (RamirezTobías et al., 2007b). The particle diameter of the gravel was 2 to $4 \mathrm{~mm}$; it was washed and disinfected with $0.20 \mathrm{ml} \mathrm{L}^{-1}$ of liquid solution of sodium hypochlorite as was stated by Calderón et al. (1997). A nutrient solution for growing cactus pear plants (Table 1) proven by Gallegos et al. (2000) was applied through sub-irrigation twice a day (09:00 and 13:00 h) on alternating days (Olmos et al., 1999). Since location where the experiment was conducted 


\begin{tabular}{ccc}
\hline Element & Concentration mg L-1 & Source \\
\hline $\mathrm{N}$ & 150.0 & $\mathrm{Ca}\left(\mathrm{NO}_{3}\right)_{2} \cdot 4 \mathrm{H}_{2} \mathrm{O}$ \\
$\mathrm{Ca}$ & 210.0 & $\mathrm{KH}_{2} \mathrm{PO}_{4}$ \\
$\mathrm{P}$ & 40.0 & $\mathrm{~K}_{2} \mathrm{SO}_{4}$ \\
$\mathrm{~K}$ & 225.0 & $\mathrm{MgSO}_{4} \cdot 4 \mathrm{H}_{2} \mathrm{O}$ \\
$\mathrm{Mg}$ & 40.0 & $\mathrm{Fe} \mathrm{chelate}$ \\
$\mathrm{Fe}$ & 5.0 & $\mathrm{MnSO}_{4} \cdot 4 \mathrm{H}_{2} \mathrm{O}$ \\
$\mathrm{Mn}$ & 2.0 & $\mathrm{CuSO}_{4} \cdot 5 \mathrm{H}_{2} \mathrm{O}$ \\
$\mathrm{Cu}$ & 0.1 & $\mathrm{ZnSO}_{4} \cdot 7 \mathrm{H}_{2} \mathrm{O}$ \\
$\mathrm{Zn}$ & 0.2 & $\mathrm{H}_{3} \mathrm{BO}_{3}$ \\
$\mathrm{~B}$ & 0.6 & $\left(\mathrm{NH}_{4}\right)_{6} \mathrm{Mo}_{7} \mathrm{O}_{24} .4 \mathrm{H}_{2} \mathrm{O}$ \\
$\mathrm{Mo}$ & 0.05 &
\end{tabular}

Table 1. Chemical composition of the nutritive solution (Gallegos-Vazquez et al., 2000) and nutrient sources used (Ramírez-Tobías et al., 2007a).

lacks piped water service, filtered runoff water was used for the nutritive solution. The nutritive solution was provided to plants through a closed irrigation system which allows recycling it. Then, the same solution was recycled during 15 days and totally replaced afterwards in order to preserve conductivity and nutrients at an adequate level. The $\mathrm{pH}$ of the nutritive solution was kept at the level of 5.8 by adding sulfuric acid (Calderón et al., 1997).

The spineless cactus pear species assessed proceeded from different climatic regions and their shoots are traditionally used either as nopalito or fodder in México. Nopalea cochenillifera (L.) Salm-Dyck lives in warm and humid regions; this species is considered the least adapted to low temperatures. Opuntia ficus-indica (L.) Mill. cv. Tlaconopal grows in temperate and subhumid climates. Opuntia robusta ssp. larreyi (Weber) Bravo, can be found in areas with temperate semidry climate with warm summer and extreme temperature variations. The hybrid Opuntia undulata Griffiths x Opuntia tomentosa Salm-Dyck is cultivated in a transitional climate from semi-warm to temperate.

Mature cladodes were planted in individual pots; the lower third of their total length was buried into the substrate. The orientation of the cladode sides was north-south due to space restrictions in the permanent greenhouse facilities. The plantation density on each bench container was 16.7 plants $\mathrm{m}^{-2}$, with a distance of $20 \mathrm{~cm}$ between rows and $30 \mathrm{~cm}$ between plants (Fig. 1).

The caulinar photosynthetic area of the parental cladodes was estimated according to Sánchez-Venegas (1995). Considering the length of mature cladode in each species, fourth growth stages (GS) of vegetative sprouts were designed (Table 2). GS were set by dividing the mean mature cladode length by four in each species, this number, when multiplied by 1 corresponded to young nopalito (GS1), middle developed nopalito (GS2) when multiplied by 2 , developed nopalito (GS3) when multiplied by 3 and mature cladode (GS4) when multiplied by 4 . As was observed, the sprouts used for nopalito coincided with young and middle developed nopalito (GS1 and GS2, respectively), although the developed nopalitos 


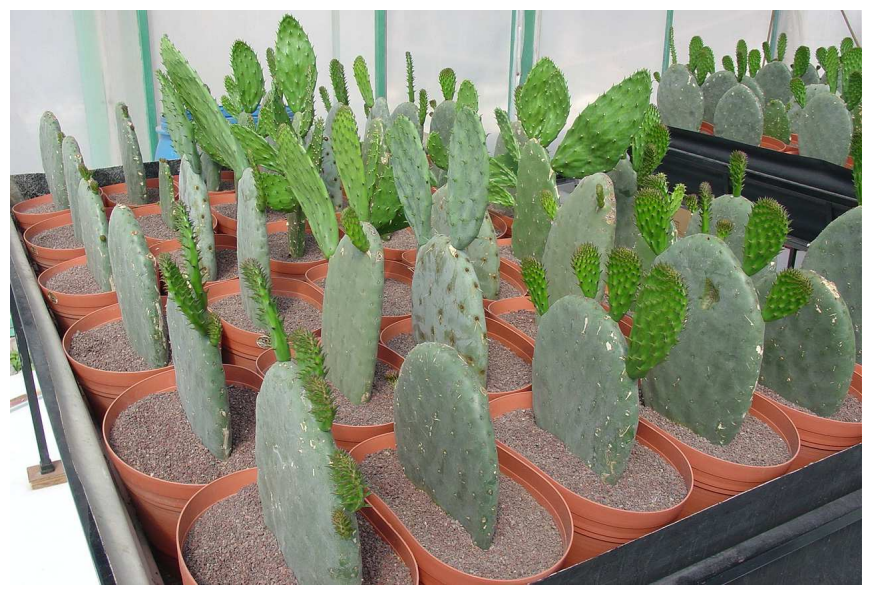

Fig. 1. Mature cladodes planted in individual pots on a hydroponic system and greenhouse (Figure took from Ramírez-Tobías et al., 2007b).

\begin{tabular}{|c|c|c|c|c|}
\hline \multirow{2}{*}{$\begin{array}{l}\text { Growth } \\
\text { stages }\end{array}$} & \multicolumn{4}{|c|}{ Species } \\
\hline & N. cochenillifera & $\begin{array}{l}\text { O. robusta ssp. } \\
\text { larreyi }\end{array}$ & $\begin{array}{c}\text { O. undulata } \times O \text {. } \\
\text { tomentosa }\end{array}$ & O. ficus-indica \\
\hline GS1 & 6 & 8 & 8 & 10 \\
\hline GS2 & 12 & 17 & 16 & 20 \\
\hline GS3 & 17 & 25 & 24 & 31 \\
\hline GS4 & 23 & 34 & 32 & 41 \\
\hline
\end{tabular}

Table 2. Size ranges, in centimeters, of the four cladode growth stages (GS) in Opuntia and Nopalea cladodes grown under hydroponic conditions. In all cases, the standard deviation is $\pm 1.5 \mathrm{~cm}, \mathrm{n}=16$ (Ramírez-Tobías, 2006).

(GS3) is used as nopalito and fodder, and the mature cladode (GS4) only as fodder. Every shoots sprouted were harvested from the parent plant from January 2005 to February 2006. Shoots sprouting and growth in each treatment was checked on alternate days, and those that had already reached the size set for the corresponding treatment were harvested and its weight quantified. Each harvest, the period of time between harvests (partial periods) and the production were recorded for each experimental unit or parental cladode. Productivity for each period ( $\mathrm{kg}$ of dry matter ha-1 $\mathrm{day}^{-1}$ ) was estimated by dividing the production by the respective number of days in the period, productivity for the whole experimental period was the sum of partial periods.

In order to study attributes related to nopalito quality $\mathrm{pH}$, resistant to flexion and penetration, color and mucilage content were assessed. The $\mathrm{pH}$ was evaluated in situ, in sprouts harvested between 13:00 and 14:00 $\mathrm{h}$ by introducing the glass electrode and the temperature probe of a portable potentiometer (Oacton $\left.{ }^{\circledR}\right)$ through an incision into a piece of nopalito (Flores-Hernández et al., 2004). Resistance to flexion and penetration measurements were carried out the day after harvesting, using a universal testing machine 
(Instron $\left.{ }^{\circledR}\right)$. Resistance to flexion was assessed as the strength needed to bend the nopalito lengthwise (longitudinal flexibility) and widthwise (transverse flexibility) by $18.5 \%$ (Rodríguez-Félix \& Villegas-Ochoa, 1997), and both measurements were averaged for each nopalito. Resistance to penetration was measured at the base, center and apex with a $1.5 \mathrm{~mm}$ diameter awl working at a speed of $100 \mathrm{~mm} \mathrm{~min}^{-1}$ (Rodríguez-Félix \& Villegas-Ochoa, 1997; Guevara et al., 2003; Anzurez-Santos et al., 2004), and a mean resistance was calculated for each nopalito.

Color was registered the day after harvest using a Hunterlab colorimeter (Accu-ProbeTM model HH06) in the apex, center and base of the nopalito. According to the Hunter system (MacDougall, 2002), lightness values $\left(L^{*}\right)$, hue angle and chroma were calculated (Sáenz, 2000; MacDougall, 2002). In order to establish mucilage content, the nopalitos were chopped into small pieces, kept in separate bags inside an ice cooler with a refrigerant gel during transportation, and then were kept at $-20^{\circ} \mathrm{C}$ in the lab. The small pieces of nopalito were dried in a laboratory freeze-drier (ilShin ${ }^{\circledR}$ model TFD5505) and ground or crushed in a mortar. The extraction and quantification as percent of mucilage in dry matter was conducted according to the procedure described by Peña-Valdivia \& Sánchez-Urdaneta (2006). This method includes extraction with hot water as solvent and its concentration by precipitation with ethanol.

Nutrimental fodder quality was assessed through the dry matter percentage, crude protein and ash content, which were obtained according to the AOAC (1990) techniques. The percentages of fiber insoluble in neutral and acid detergents were determined following the Van Soest et al. (1991) methods.

A random full-block experimental design was used, with a factorial arrangement of treatments and four replicates. Factors evaluated were cactus pear species (four) and growth stage; evaluations of nopalito quality attributes were made on growth stage one, two and three, and those of productivity and nutrimental fodder quality were made on the four growth stages. Then the experimental units assessed for nopalito quality attributes were a total of 48 and for productivity and nutrimental fodder quality were 64 . The data of productivity were analyzed through a covariance analysis in which the caulinar photosynthetic area of parental cladodes was used as a covariable. Variables characterizing the quality of nopalitos and fodder were analyzed through a variance analysis and a multiple comparison of means. The SAS software was used for conducting statistical analysis through the GLM and LSMEANS procedures (SAS, 1990). The pattern of biomass accumulation was estimated by plotting the cumulative production of partial harvest periods against time. Then, the model that best fits the data of each treatment against time was selected with SigmaPlot Jandel Scientific software (version 10) for the personal computer, this software was also used for selection of the best-fit models.

\section{Results}

\subsection{Nopalito and forage productivity}

Plant productivity is defined as the rate of energy stored from photosynthetic activity (Odum, 1972); then it is a continuous process in which growth is affected by environmental factors (Nobel, 1988). Nopalito producers usually take its size as one criterium to cut the shoot intended for marketing. As an example, small nopalitos are considered as a high 
quality product (Flores \& Olvera, 1994) which is confirmed by its excellent chemical and physical characteristics (Cantwell, 1992; Rodríguez-Félix \& Cantwell, 1988); also authors observed that this kind of nopalitos takes prices in Mexican markets 50 to $100 \%$ higher than big ones. On the other hand, nutrimental quality of the bigger cladodes, usually used as fodder, is diminished with growth as will be indicated forward. Notwithstanding, research works cited along this paper, evaluating yield and nutrimental characteristics as fodder, usually refers that harvest of cladodes was made on fixed equal periods which is distantly linked with natural growth of the cladodes. Then, information corresponds to a wide range of sizes available at the time of the cut. Thereby in this work, productivity was analyzed on specific cladode sizes which are compatible with those of nopalito and fodder (Table 2).

Cladode productivity increased directly as harvest was carried out at increasing sizes, and the pattern of increase is different among species (Fig. 2). Conversely, the harvest of small cladodes as is made when they are cut to use them as nopalitos limits productivity and the harvest of mature cladodes enhance productivity. The productivity increase due to increasing size of the cladode showed some differences among species, being exponential in O. ficus-indica cv. Tlaconopal, O. undulata $\times$ O. tomentosa and N. cochenillifera, and linear in O. robusta ssp. larreyi (Fig. 2). The more pronounced increase in biomass with respect to growth stage at harvest, seem to be due to secondary growth (García de Cortázar \& Nobel, 1992), characterized by cell wall lignification (Collins \& Fritz, 2002). The linear relationship between productivity and growth stages in O. robusta ssp. larreyi may be explained by its low lignin content respecting to the other three species (Ramírez-Tobías et al., 2007a).

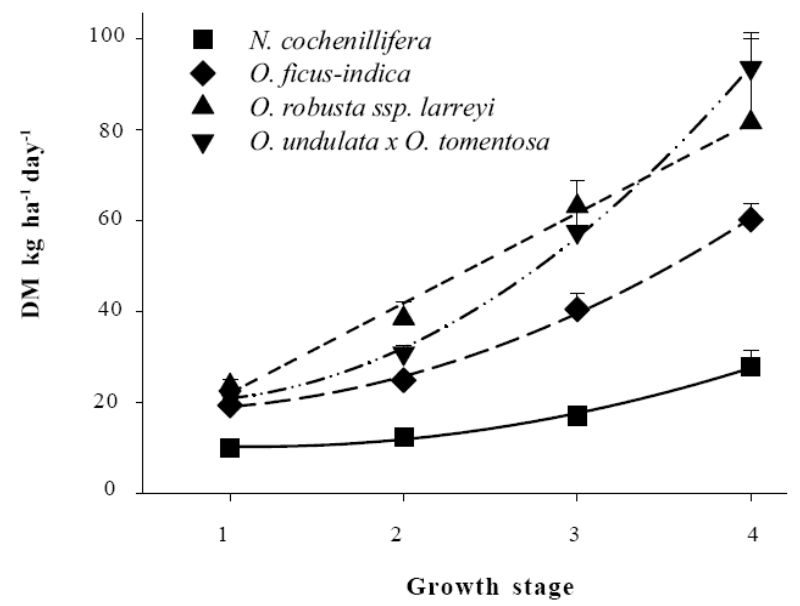

Fig. 2. Effects of the development stage on cactus pear productivity grown under hydroponics. Bars indicate standard errors. Shoots were harvested from the parent plant from January 2005 to February 2006 (Figure from Ramírez-Tobías et al., 2010).

The productivity when harvest was made on the first growth stage kept some similarity with the second growth stage. Although a tendency to increase productivity was registered only in O. robusta ssp. larreyi (Fig. 2). This fact allows recommending the harvest of younger sprouts since yield did no augment for harvesting some bigger cladodes and savvy consumers might pay higher prices as was indicated before. Moreover, at least in Mexico, 
nopalitos marketing is more common in small cut pieces, which cause confusion in the consumer's perception of the quality of nopalito. Likewise, productivity of very young nopalitos of $O$. robusta ssp. larreyi is nearly doubled by that of bigger tender cactus in the same species, and a demerit occurs on visuals attributes associated with quality (LópezPalacios et al., 2010). Then, recommendation as indicated should take into account variation in quality attributes due to maturity.

Cladode productivity was statistically similar between growth stages three and four, excepting $O$. robusta ssp. larreyi which productivity of cladodes in growth stage four was significantly higher than productivity in growth stage three (Fig. 2). As will be described forward, cladode maturation both in soil and in hydroponics is characterized by a reduction in its quality as fodder (Gregory \& Felker, 1992; Ramírez-Tobías, et al., 2007a). Moreover, in Opuntia species, from early mature cladode (growth stage three) to mature cladode (growth stage four) only insoluble fiber in neutral detergent increased and dry matter percent decreased significantly while other attributes as crude protein content, insoluble fiber in neutral detergent and ash kept without significant changes; although in $N$. cochenillifera crude protein, insoluble fiber in neutral detergent kept without changes (Ramírez-Tobías et al., 2007a). The lack of statistical differences in productivity when harvest early mature cladodes and full mature ones allows us to recommend the use of inmature cladodes, although species differences must be taken into account.

With the cladodes of bigger sizes, productivity increased further in Opuntia than in Nopalea species. From the second growth stage, productivity differences among Opuntia species were larger than with Nopalea. Two species, O. robusta ssp. larreyi and O. undulata $\times$ O. tomentosa showed the highest productivity; in contrast, N. cochenillifera the lowest (Fig. 2). Differences in productivity among Opuntia and Nopalea species can be due to adaptation to climatic conditions of their respective regions, specifically to temperature. Climatological data of $O$. robusta ssp. larreyi and O. undulata $\times$ O. tomentosa areas suggest ample temperature variation in daily and seasonal patterns (García, 2004). Then, the higher productivity of these species might be due to their higher tolerance to broad daily and seasonal temperature variations recorded in the greenhouse, which had not additional controls of temperature (Ramírez-Tobías, 2006). In contrast, climate patterns from regions of $N$. cochenillifera and $O$. ficus-indica cv. Tlaconopal, have less daily and seasonal variations of temperatures; first species has its optimum around a warm temperature regime and second with optimum around a temperate temperature regime (García, 2004). Probably, temperature variations inside the greenhouse inhibited the growth of the less-tolerant species, resulting in lower productivities. The low productivity of Nopalea in relation with Opuntia recorded in hydroponics also could be explained by temperature effects. In the north-east semidry region of Brazil, on field conditions, the fodder productivity of $N$. cochenillifera and O. ficusindica cv. Tlaconopal was statistically similar (Gonzaga \& Cordeiro, 2005). Temperature reported for some Brazilian regions where $N$. cochenillifera and O. ficus-indica growth (Cordeiro et al., 2004) has some correspondence with that of $N$. cochenillifera regions in Mexico (Sánchez, 1995). Thus, differences in productivity between Nopalea and Opuntia could be indicative of genetic differences between both genera, particularly in low temperature tolerance.

The biomass accumulation pattern of Opuntia and Nopalea from the younger sprouts to the mature ones coincides with the patterns of perennial plants. Along a year of continuous 


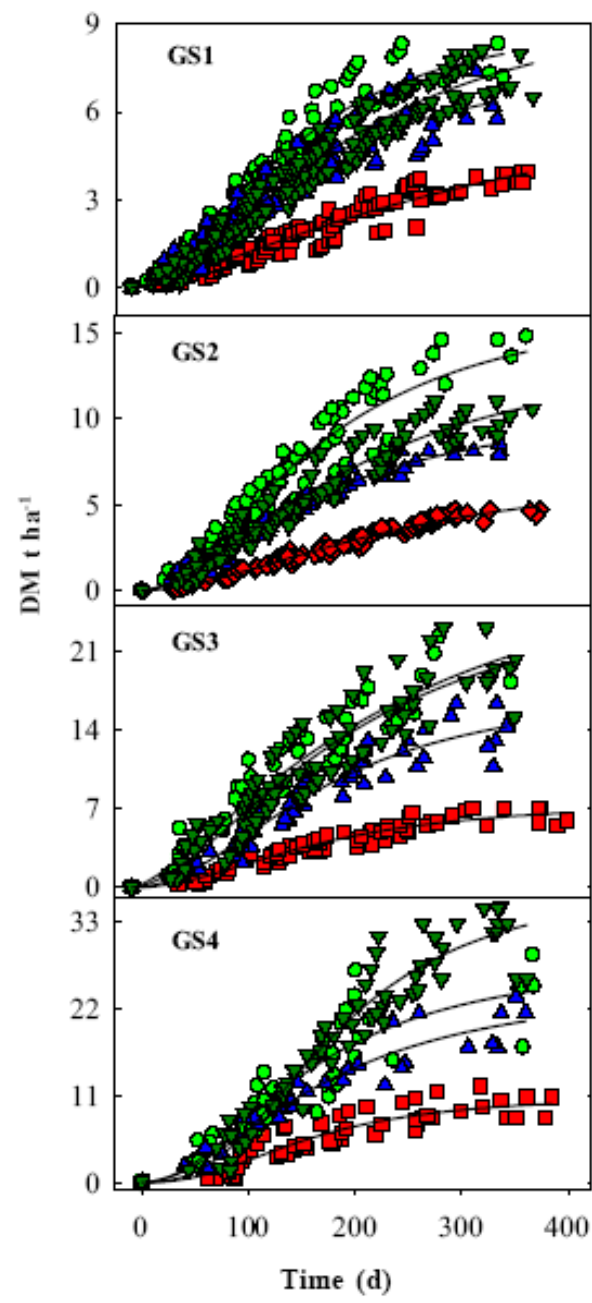

- N. cochenillifera

- O. robusta ssp. larreyi

- O. ficus-indica

$\nabla \quad$ O. undulata $\mathrm{x}$ O. tomentosa

Fig. 3. Biomass accumulation pattern in three Opuntia and one Nopalea species harvested at four different cladode sizes. (From Ramírez-Tobías et al., 2010).

harvest at the four different cladode sizes, the biomass accumulated shows a sigmoid pattern (Fig. 3). Along this time, accumulated production showed an initial lag phase lasting 40 days, followed by an exponential rise phase lasting up to 200 days, and a late stabilization phase of accumulating production (Fig. 3). Since data referred are from cactus pear growing in hydroponics under a greenhouse lacking of temperature control, it is possible suggest that temperature could be a limiting factor. In fact, inside the greenhouse, the monthly average temperature varied around $8{ }^{\circ} \mathrm{C}$ during the registered period (Fig. 4). Furthermore, the raise in monthly average temperature coincided with the accelerated increase on linear phase of the sigmoid trend, and the late stabilization phase seems to be associated to the drop in greenhouse temperature (Figs. 3 and 4). 


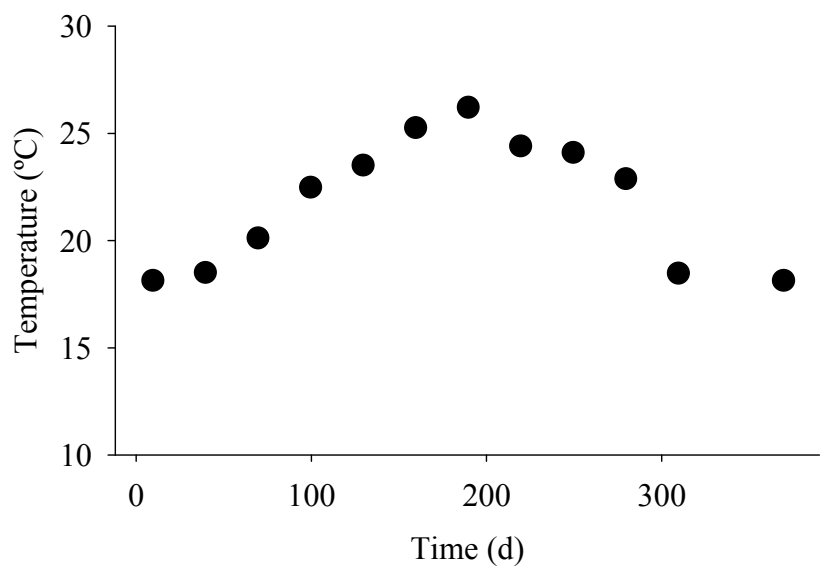

Fig. 4. Trend of the monthly average temperature registered inside the greenhouse where $O$. ficus-indica, O. robusta ssp. larreyi, O. undulata and O. tomentosa and N. cochenillifera grew along a full year.

The hydroponics clearly increased productivity of cactus pear. O. ficus-indica cv. Tlaconopal is a low productive species that yielded much more in hydroponics than in soil (Table 3). In the case of the mature cladode (GS4), the productivity was of 21, 24 and $32 \mathrm{t}$ of dry matter ha-1 $\mathrm{yr}^{-1}$ in O. ficus-indica cv. Tlaconopal, O. robusta ssp. larreyi and O. undulata $\times$ O. tomentosa, respectively, a value far higher than productivity registered on intensive systems on soil (Table 3). A productivity of $47 \mathrm{t}$ of dry matter $\mathrm{ha}^{-1} \mathrm{yr}^{-1}$ was estimated for O. ficus-indica irrigated daily with a nutrient solution and with special care in promoting high efficiency in the use of solar radiation (Nobel et al., 1992). Hence the productivity of Opuntia may be extremely high when optimal conditions are provided (Nobel, 1988), as under hydroponics (Mondragón-Jacobo et al., 2001; Ramírez-Tobías et al., 2010).

\begin{tabular}{lcccc}
\hline \multicolumn{1}{c}{ Production system } & $\begin{array}{c}\text { Nopalito } \\
\text { (GS 1) }\end{array}$ & $\begin{array}{c}\text { Nopalito } \\
\text { (GS 2) }\end{array}$ & $\begin{array}{c}\text { Nopalito / } \\
\text { Fodder } \\
\text { (GS 3) }\end{array}$ & $\begin{array}{c}\text { Fodder } \\
\text { (GS 4) }\end{array}$ \\
\hline $\begin{array}{l}\text { Hydroponics } \\
\text { Traditional row } \\
\text { system }\end{array}$ & $142^{1}$ & $264^{1}$ & 4701 & $21^{1}$ \\
\begin{tabular}{l} 
Intensive system \\
\hline
\end{tabular} & 40 to $90^{2}$ & & \\
\hline
\end{tabular}

Table 3. Comparison of productivity of production systems of O. ficus-indica. From GS 1 to GS 3 values are tons of cladodes (Fresh matter, FM) ha-1 $\mathrm{yr}^{-1}$ and in GS4 values are tons of cladodes (Dry matter, DM) ha-1 $\mathrm{yr}^{-1}$. Based on Ramírez-Tobías et al., 20101, Flores \& Olvera, 1994, Blanco-Macías et al., $2004^{2}$ and Gonzaga \& Cordeiro, 20053).

The criterion used by cactus pear farmers and collectors for harvesting or gathering vegetative shoots, either for nopalitos or fodder, is cladode size, or growth stage as was made in this work. This fact contrasts with criterion generally used where fixed time periods are investigated. As will be indicated, quality of sprouts decays with maturity of the cladode 
(López-Palacios et al., 2010; Ramírez-Tobías et al., 2007a). Subsequently, harvest would require a given frequency for best approximation to a cladode size and a desired quality. When cladode size is used to determine the moment of cut, the average period of time between harvests augment; consequently, frequency of harvest is inversely related to the size of cladode at the cut moment. The ideal situation would be achieving high harvest efficiency, it means, a low harvest frequency coupled with a high production every harvest (Ramírez-Tobías et al., 2010). Besides, the harvest frequency depend on the species; O. ficusindica $\mathrm{cv}$. Tlaconopal and O. robusta ssp. larreyi showed the longest mean periods between harvests, whereas the hybrid variants required the most frequent harvests (Table 4).

\begin{tabular}{lcccccccc}
\hline \multirow{2}{*}{ Species } & \multicolumn{2}{c}{ GS1 } & \multicolumn{2}{c}{ GS2 } & \multicolumn{2}{c}{ GS3 } & \multicolumn{2}{c}{ GS4 } \\
\cline { 2 - 8 } & AIH & AH & AIH & AH & AIH & AH & AIH & AH \\
\hline N. cochenillifera & $9 \pm 1$ & $35 \pm 7$ & $13 \pm 2$ & $28 \pm 5$ & $20 \pm 1$ & $20 \pm 1$ & $23 \pm 9$ & $16 \pm 4$ \\
O. robusta ssp. larreyi & $11 \pm 2$ & $28 \pm 5$ & $14 \pm 2$ & $23 \pm 3$ & $19 \pm 5$ & $15 \pm 2$ & $28 \pm 9$ & $11 \pm 2$ \\
O. ficus-indica & $12 \pm 1$ & $27 \pm 3$ & $18 \pm 2$ & $19 \pm 3$ & $21 \pm 3$ & $16 \pm 2$ & $35 \pm 3$ & $10 \pm 1$ \\
$\begin{array}{l}\text { O. undulata } \times \text { O. } \\
\text { tomentosa }\end{array}$ & $9 \pm 1$ & $40 \pm 1$ & $13 \pm 1$ & $27 \pm 1$ & $15 \pm 2$ & $22 \pm 2$ & $21 \pm 2$ & $17 \pm 2$ \\
\hline
\end{tabular}

Table 4. Harvest frequency (average period and number of harvests) according to the growth stage (GS) at the cutting moment of four cactus pear species during an experiment evaluation from January 2005 to February 2006. (AIH, average interval time between harvests (days); $\mathrm{AH}$, average number of harvests completed). Values after the sign \pm indicate the standard deviation (From Ramírez-Tobías et al., 2010).

\subsection{Nutrimental fodder quality}

Nutrimental quality was affected significantly by the maturation of each single cladode (Ramírez-Tobías et al., 2007a). As cladode grows and matures, crude protein diminished; protein content is considered a strong indicator of the quality of forages, but in cactus pear cladodes it diminished significantly from the smaller sizes of the cladodes (young and middle development nopalitos, GS1 and GS2) to the bigger ones (developing nopalito and mature cladode, GS3 and GS4) (Fig. 5). Similar findings have been observed in cladodes of Opuntia and Nopalea (Gregory \& Felker, 1992; Nefzaoui \& Ben Salem, 2001) and in other forages (Collins \& Fritz, 2003). Reductions in the protein content occur due to translocation of amino acids to younger organs or tissues which present higher metabolic activity than older ones (Nobel, 1983). Calculations considering crude protein content and production show that absolute protein content harvested in the mature cladodes did not reduce because increase in biomass compensates the decrease in protein content percentage (Ramírez-Tobías, 2006).

Insoluble fibers in neutral and acid detergents augment significantly from the younger growth stages to the older ones in Opuntia species while in Nopalea insoluble fiber in neutral detergent decreased and insoluble fiber in acid detergent slightly augmented (Fig. 5). Although, the significant increase of both fibers in Opuntia species with maturity, the increases in insoluble fibers in neutral detergent were greater than in insoluble fibers in acid detergent. The increase of both types of fibers is common in plants since is a result of lignifications processes due to maturation (Collinz \& Fritz, 2003; De Alba, 1971), but smaller increase of insoluble fibers in acid detergent could evidence incipient lignifications. In fact, 


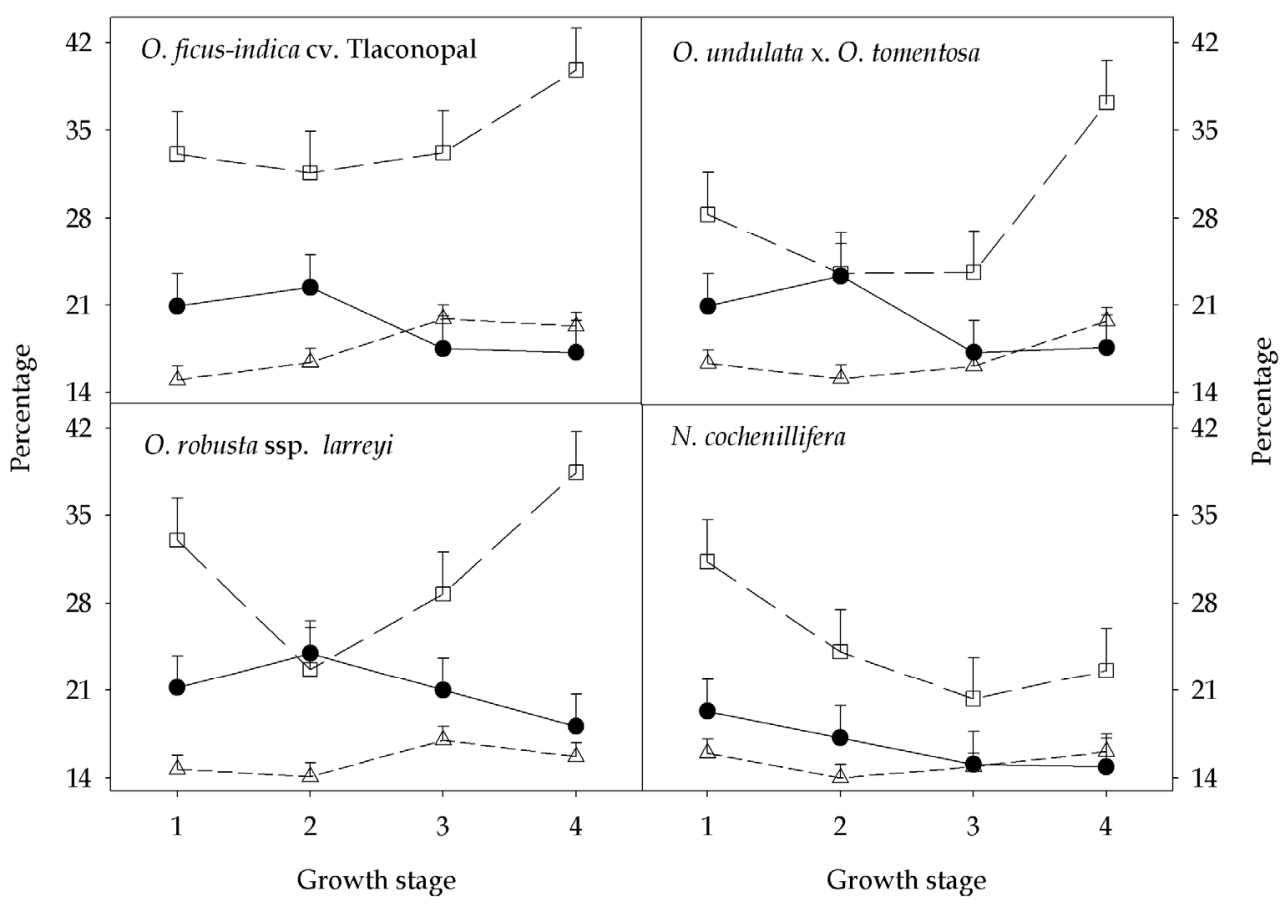

Fig. 5. Changes on the nutritional content due to maturity of cladodes of three Opuntia species and one of Nopalea grown in hydroponics under a greenhouse. (-- --- Insoluble fiber in acid detergent, $-\square-$ insoluble fiber in neutral detergent and $\longrightarrow \longrightarrow$ crude protein). Vertical bar indicate standard error. (Modified from Ramírez-Tobías et al., 2007a).

very young Opuntia cladodes lack lignin (Peña-Valdivia \& Sánchez-Urdaneta, 2004). Conversely, the fiber increase of cladodes produced in hydroponics probably does not affect digestibility since its dry matter digestibility averaged 90\% (Mondragón-Jacobo et al., 2001), while dry matter digestibility of cladodes produced on soil averaged 70 to $75 \%$ (Gonzaga \& Cordeiro, 2005; Pinos-Rodríguez et al., 2006). Then, the increase of fibers in cladodes might involve mainly cellulose and hemicelluloses, which do not diminish nutrimental quality of cladode produced in hydroponics.

Ash of cladodes produced in hydroponics increased significantly with the maturity (Fig. 6). Similar findings were documented in cladodes over different cactus pear plants (FloresHernández et al., 2004) and in young and mature cladodes of O. ficus-indica cv. Tlaconopal (Rodríguez-Garcia et al., 2008). The augment on ash content is due to mineral accumulation, mainly calcium (Nobel, 1983; Rodríguez-Garcia et al., 2008). The increasing ash content due to maturity might reduce quality of the cladode as fodder since ash content is negatively correlated to digestibility (Pinos-Rodríguez et al., 2006). Notwithstanding, ash is a synonym of minerals (De Alba, 1971) and its input to the feeding of cattle and humans is relevant (Mcconn \& Nakata, 2004).

Accumulation of ash through growth took different patterns among species. In the three Opuntia species, the ash content augmented with age of the cladode until developing 


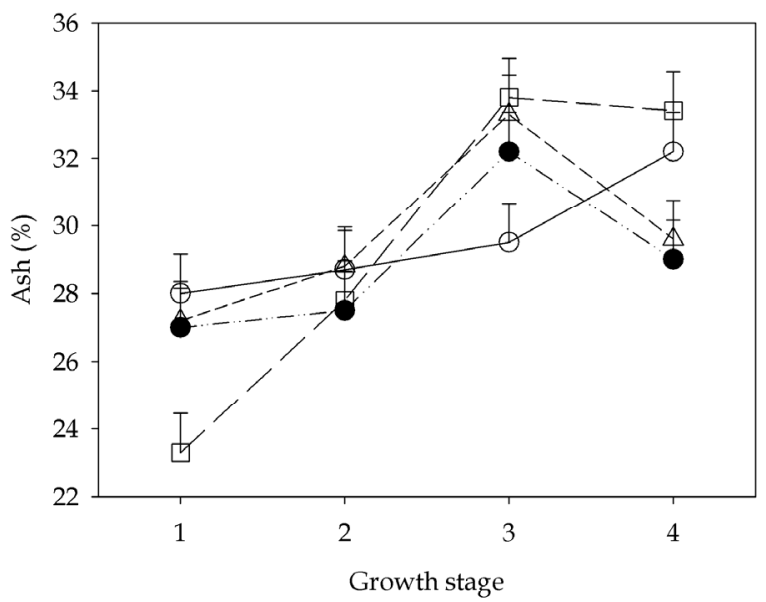

Fig. 6. Effect of maturity over the ash content of Opuntia ficus-indica ( $-\boxminus-)$, O. robusta ssp. larreyi $\left(--A_{--}\right)$, O. undulate x. O. tomentosa (---) and Nopalea cochenillifera $(-\mathrm{O})$ cladodes produced in hydroponics under greenhouse. Vertical bars indicate the error standard. (From Ramírez-Tobías et al., 2007a).

nopalito (growth stage three); but from this point, ash did not change through fourth stage in O. ficus-indica cv. Tlaconopal while in O. robusta ssp. larreyi and in the hybrid species it reduced significantly. By the other hand, the augment on ash content on $N$. cochenillifera followed a continuous increase tendency from young nopalito (growth stage one) through mature cladode (growth stage four) (Fig. 6). Mineral content in plants depend on diverse factors as species, nutrient availability, age and others (Gárate \& Bonilla, 2000). Since hydroponics system under greenhouse provided suitable growth conditions and high nutrient availability, it is possible to infer that different ash content on species over dissimilar growth stage is a genotype expression of different capacity of nutrient absorption and accumulation.

Dry matter percentage of cladodes produced in hydroponics was significantly higher in young nopalito (growth stage one) and decreased as cladode grows until an inflexion point from which it tended to augment (Fig. 7). The highest dry matter percentage registered on first growth stage could be explained by a higher rate area/volume observed in young cladodes than in older ones (Ramírez-Tobías et al., unpublished data). As cladode grows, tissues specialized in water store develop and percentage of water content get up, then dry matter percentage get down. Inflexion point of increase in dry matter percentage may be a result of medullary parenchyma development (Rodríguez \& Cantwell, 1988) and accumulation of hemicelluloses and lignin associated with maturation. Inflexion point in dry matter percentage of $O$. ficus-indica $\mathrm{cv}$. Tlaconopal and O. robusta ssp. larreyi was reached at growth stage three and for the hybrid species at growth stage two. Dry matter percentage during maturation of $N$. cochenillifera showed a different pattern from those of Opuntia species (Fig. 7). Differences in the pattern of dry matter percentage through growth stages on Opuntia species, and the highly marked difference observed between Opuntia and Nopalea genera suggest adaptive differences among genotypes in this respect. 


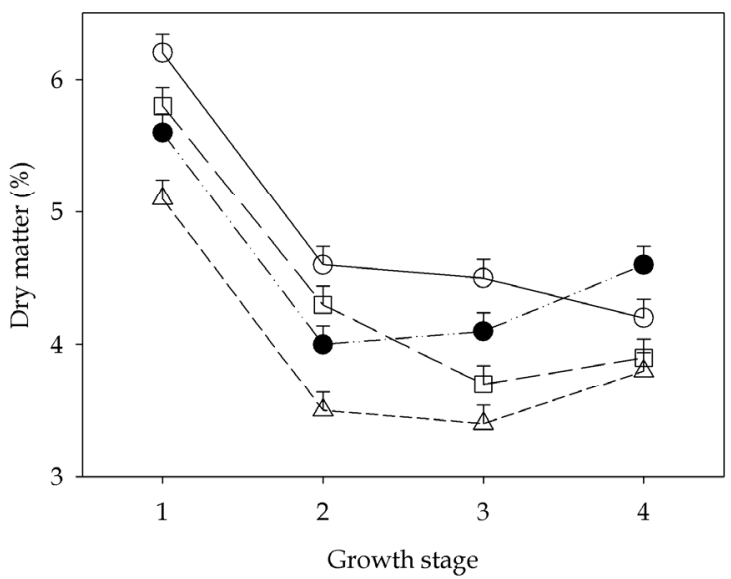

Fig. 7. Effect of maturity over the dry matter content of Opuntia ficus-indica cv. Tlaconopal ( $-\boxminus-)$, O. robusta ssp. larreyi (-- ---$)$, O. undulate x. O. tomentosa (- - - ) and Nopalea cochenillifera $(-\mathrm{O})$ cladodes produced in hydroponics under greenhouse. Vertical bars indicate the error standard. (From Ramírez-Tobías et al., 2007a).

Regardless maturation effect, $O$. ficus-indica cv. Tlaconopal presented the highest insoluble fiber in neutral and acid detergent content and $N$. cochenillifera tend to show the lowest one (Ramírez-Tobías et al., 2007a \& Fig. 5). High fiber content of O. ficus-indica is related to higher resistance to flexion and penetration as regard to other cactus pear species (LópezPalacios et al., 2010). Mechanical support is one of the functions of fibers (García \& Peña, 1995). Moreover greater fiber content of O. ficus-indica cv. Tlaconopal might be an adaptation to support the weight of its cladodes, far bigger than those of $N$. cochenillifera (Ramírez-Tobías et al., 2007a).

Cladodes produced in hydroponics showed divergent dry mater percentage (Fig. 7); N. cochenillifera had the highest, O. robusta ssp. larreyi the lowest, and O. ficus-indica cv. Tlaconopal and the hybrid species medium contents. Since dry matter is the opposite of water content, it could be established that O. robusta ssp. larreyi have the greatest capability of water store while $N$. cochenillifera have the lowest one. Their greatest capability for water store allows $O$. robusta ssp. larreyi to thrive in areas with annual precipitation around 400 $\mathrm{mm}$ or lesser, and the smallest capability of $N$. cochenillifera is only sufficient to survive in regions with $1000 \mathrm{~mm}$. Intermediate competence for storing water of O. ficus-indica cv. Tlaconopal and the hybrid species require a medium precipitation quantity, $700 \mathrm{~mm}$, as that recorded in places where they are found (García, 2004; Ramírez-Tobías et al., 2007a).

The nutrimental quality of the sprouts produced in hydroponics for animal feed is high. In cladodes produced in hydroponics, crude protein content is four times higher than that of cladodes produced on soil systems (Table 5), and it is comparable with that of high quality forages as alfalfa (De Alba, 1971). The high crude protein content in the dry matter of cladodes produced on hydroponics may be explained by the close relationship between the available nutrients in the nutritive solution and the $\mathrm{N}$ in the tissues (Gallegos-Vázquez et al., 2000; Nobel, 1983). Also, ash content and insoluble fiber in neutral detergent are higher in cladodes produced in hydroponics than those produced on soil, but insoluble fiber in acid 


\begin{tabular}{|c|c|c|c|c|c|}
\hline \multirow{2}{*}{$\begin{array}{c}\text { Form of } \\
\text { production }\end{array}$} & \multirow{2}{*}{$\begin{array}{l}\text { Crude } \\
\text { protein }\end{array}$} & \multirow[b]{2}{*}{ Ash } & \multicolumn{2}{|c|}{ Insoluble fiber in } & \multirow[b]{2}{*}{ Source } \\
\hline & & & $\begin{array}{c}\text { Neutral } \\
\text { detergent }\end{array}$ & Acid detergent & \\
\hline Soil & 4.1 & 21.6 & 24.7 & 16.3 & $\begin{array}{c}\text { 1Pinos-Rodriguez et } \\
\text { al., } 2003\end{array}$ \\
\hline Hydroponics & 16.9 & 31.1 & 34.5 & 17.7 & $\begin{array}{c}\text { 2Ramírez-Tobías et } \\
\text { al., } 2007\end{array}$ \\
\hline
\end{tabular}

Table 5. Nutrimental attributes of cladodes grown on different systems. ${ }^{1}$ Data are the average of $O$. ficus-indica, O. robusta and O. rastrera. ${ }^{2}$ Data are the average of Nopalea cochenillifera, O. ficus-indica, O. robusta ssp. larreyi and O. undulata $\times$ O. tomentosa.

detergent resulted only slightly superior (Table 5). Since ash content and insoluble fiber in neutral detergent of cladodes grown on soil were partially negatively correlated with digestibility (Pinos-Rodríguez et al., 2003), cattle feed basing on cactus pear cladodes has been recommended for short time periods, from two to three months (Gutierrez \& Bernal, 2004). Nonetheless, ash of cladodes produced on hydroponics can provide enough $\mathrm{Ca}, \mathrm{P}, \mathrm{K}$ and $\mathrm{Zn}$ for maintenance and production of cattle (Mondragón-Jacobo et al., 2001). Moreover, it was stated that the Opuntia dry matter of cladodes produced on soil stays for a short time in the rumen (16 to $48 \mathrm{~h}$ ) and does not affect feed intake (Pinos-Rodríguez et al., 2003), and digestibility of cladodes produced in hydroponics was higher than that of cladodes produced on soil (Mondragón-Jacobo et al., 2001; Pinos-Rodríguez et al., 2003). High ash content in young cladodes (nopalitos) obtained in hydroponics is also relevant in people nutrition since nopalitos could be an important source of minerals (Rodríguez-García et al., 2007). Also richness in fibers may contribute to the control of cholesterol and the prevention of some diseases (Sáenz, 2000).

\subsection{Nopalito quality}

The resistance to the flexion and penetration forces, parameters associated with turgidity and fibrouness, presented differences among species and growth stages. In sprouts produced under hydroponics system, the flexion and penetration resistances increased with the maturation of the cladode (Fig. 8) (López-Palacios et al., 2010). In O. robusta ssp. larreyi from young to development nopalitos (growth stage 1 to 3 ) had an increased in resistance to longitudinal flexion, whereas nopalitos from other species did not require a greater force to bend. Developing nopalitos (growth stage 3 ) of the four species required a greater force to bend transversally (Fig. 8).

The sprouts of N. cochenillifera and O. ficus-indica cv. Tlaconopal demanded the higher force to be penetrated, and the hybrid species and O. robusta ssp. larreyi that required the lower one. During maturity, the nopalitos more developed registered the higher resistance to be penetrated $(3 \mathrm{~N})$. Young and middle developed nopalitos (growth stages 1 and 2 ) of O. ficusindica cv. Tlaconopal and $N$. cochenillifera had higher resistance than those of $O$. undulata $\times O$. tomentosa and O. robusta ssp. larreyi. Nopalitos of O. ficus-indica $\mathrm{cv}$. Tlaconopal displayed the highest resistance to penetration, while those of other species did not showed significant differences in penetration resistance (Fig. 8). 


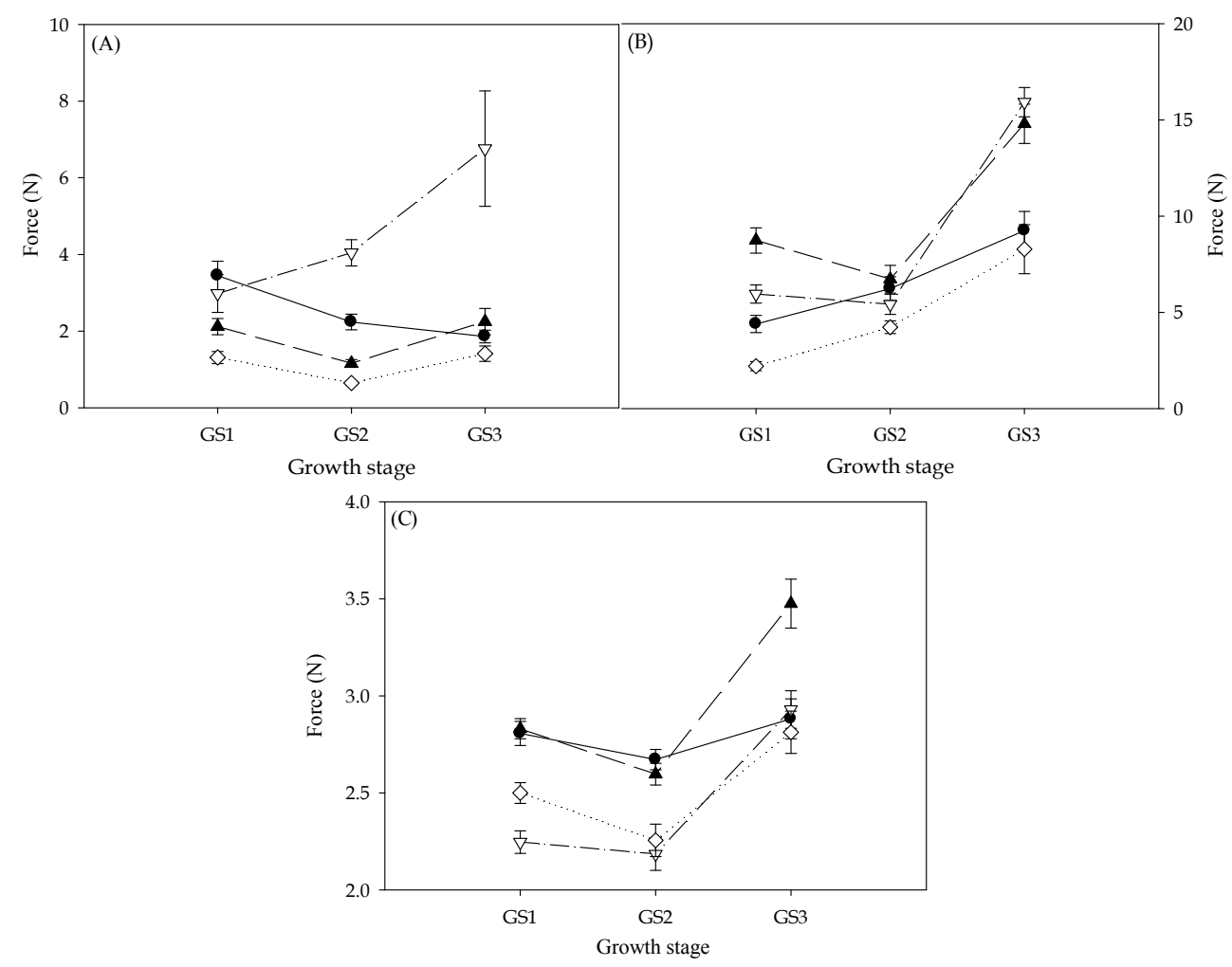

Fig. 8. Resistance to the longitudinal (A) and transversal flexion (B) and, (C) penetration force in four species at three growth stages produced in hydroponics system. $(\bullet) N$. cochenillifera, $(\mathbf{\Delta})$ O. ficus-indica, $(\nabla)$ O. robusta ssp. larreyi and $(\diamond)$ O. tomentosa $\times$ O. undulata. (From López-Palacios et al., 2010).

The resistance to flexion and penetration are related to turgidity, which is a parameter defined by Cantwell (1995) as an indicator of good quality in nopalitos. Greater turgidity might result in greater resistance. Physiologically, when there is absence of hydric stress the plant storages the water in the parenchyma cells and produces an increase in the bending force as well as a decrease in penetration resistance. Also the increase in both parameters with development might have derived from an increase in cellulose and lignin content (García \& Peña, 1995). Guevara et al. (2003) observed a low resistance to penetration in $O$. ficus-indica cv. Tlaconopal nopalitos associated with a lower crude fiber content, which consist of lignin, mostly cellulose and, in some cases, a small portion of hemicellulose (García \& Peña, 1995). Other authors (Rodríguez-Felix \& Villegas-Ochoa, 1997) found a higher resistance to penetration in partially dehydrated nopalitos, since stored water causes a reduction in resistance to penetration (Gibson \& Nobel, 1986).

The hardness of nopalitos also could be associated with their anatomy (BetancourtDomínguez et al., 2006). To observe the effect of the cuticle on the resistance to penetration, its thickness was measured in 1 year-old cladodes from each species. The cellulose and 
lignin distribution was also observed in transversal sections after staining with safranin and fast green respectively. Nopalea cochenillifera had the thinnest cuticle and also O. ficus-indica the thickest. Hypodermis cell walls displayed the greatest safranin staining and five to six rows of hypodermal cells and calcium oxalate crystals. Likewise, parenchyma cells appeared to have the highest cellulose content. These results seem to indicate that the resistance of penetration depend more on hypodermal cell-wall lignification and calcium oxalate crystals than on the characteristics of the cuticle and epidermis. Nevertheless, the accumulation of calcium oxalate reduces the food quality because these compounds bind essential minerals and form complexes that decrease calcium absorption (Contreras-Padilla et al., 2011). Although we did not make a study about of presence of calcium oxalate during development of sprouts produced under hydroponics, the increased of ash observed above from mid-developed sprouts to mature sprouts is relate to the calcium presence and with the increase in penetration resistance as it was observed by Contreras-Padilla et al. (2011) in cladodes developed on soil.

Mucilage is a slime substance exuded from tissue cutting, characteristic of nopalitos, that is part of the soluble dietary fiber. Its content may affect the consumer preference (CalvoArriaga et al., 2010), which may vary regionally or according to cultural factors, but no data are available on the optimum mucilage content. In this study, the highest mucilage content was observed in N. cochenillifera with $8.27 \%$ and the lowest in O. ficus-indica cv. Tlaconopal with $5.34 \%$, while the $O$. robusta ssp. larreyi and the hybrid species had an intermediate content. Each species studied displayed a different pattern on mucilage content in relation to the stage of growth (Fig. 9). Thus, the mucilage percentage of O. undulata $\times$ O. tomentosa nopalitos was directly related with maturity. As for the other species, O. ficus-indica cv. Tlaconopal showed the lowest mucilage content during its development. These differences on mucilage content are related with genetics differences among species; thus, the highest mucilage content of $N$. cochenillifera may be related to water balance in the warm and humid environment where it grows. Likewise, the $N$. cochenillifera sprouts showed the highest neutral-detergent insoluble fiber content and an increase in dietary fiber from middle
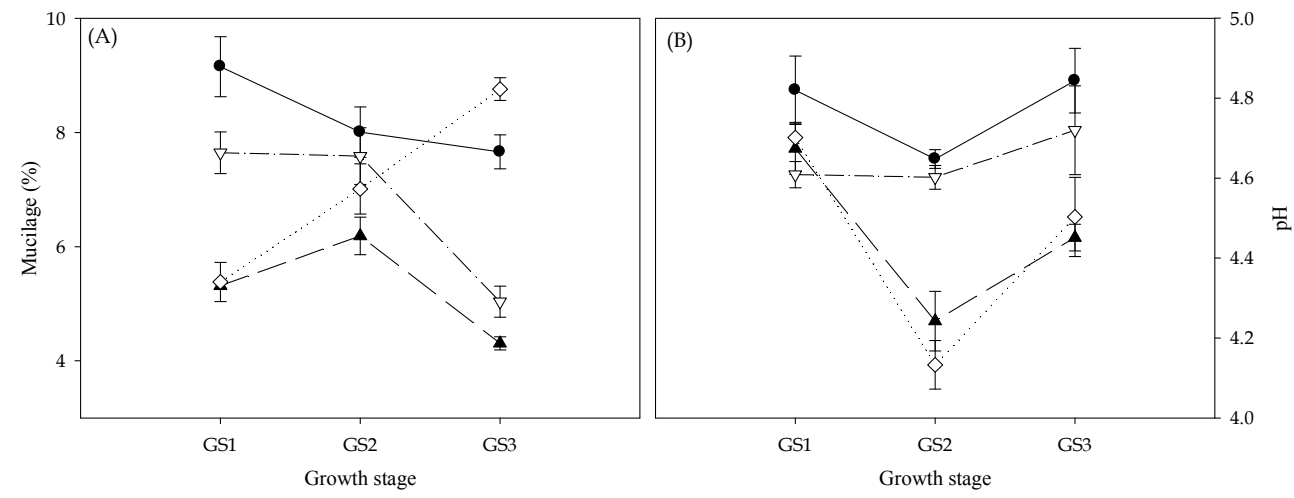

Fig. 9. Content of mucilage (A) and acidity as $\mathrm{pH}(\mathrm{B})$ in four species of nopalitos at three growth stages produced in a hydroponics system. $(\bullet)$ N. cochenillifera, $(\mathbf{\Delta})$ O. ficus-indica, $(\nabla)$ O. robusta ssp. larreyi and $(\diamond)$ O. tomentosa $\times$ O. undulata (Modified from López-Palacios et al., 2010). 
developed nopalitos (Ramírez-Tobías et al., 2007a). Some studies have shown that exist an inverse relationship between soluble and insoluble fiber content in nopalitos (LópezPalacios et al., 2011; Peña-Valdivia \& Sánchez-Urdaneta, 2006), which may explain those differences between Nopalea and Opuntia genus during development of the nopalitos.

The acid flavor of nopalitos affects the consumer preference. The $N$. cochenillifera nopalitos had the highest $\mathrm{pH}$ value (4.77), and O. undulata $\times$ O. tomentosa the lowest (4.47). Moreover, the $\mathrm{pH}$ values decreased from younger nopalitos (growth stage 1 ) to middle developed ones (growth stage 2) and then increased from middle developed nopalitos (growth stages 2) to developed ones (growth stage 3) in N. cochenillifera, O. ficus-indica cv. Tlaconopal and O. undulata $\times$ O. tomentosa sprouts (Fig. 9). These changes observed during the growth were similar to the showed by field-grown nopalitos (Betancourt-Dominguez et al., 2006). In contrast, the $\mathrm{pH}$ values in nopalitos of $O$. robusta ssp. larreyi remained constant during development. A study registered that the $\mathrm{pH}$ decreased in nopalitos as growth progressed (Rodríguez-Felix \& Cantwell, 1988); a different pattern was observed in our investigation. Pimienta-Barrios et al. (2005) observed a shift from CAM (crassulacean acid metabolism) to $\mathrm{C}_{3}$ matabolic pathway in nopalitos grown under irrigation which caused an increase of $\mathrm{pH}$. This metabolic shift has already been related to water availability (Cushman, 2001), so what in this shift in the photosynthetic pathway can have happened young and development nopalitos (growth stage 1 and 3 , respectively).

The color of nopalitos, as hue angle, was between green and yellow and increased with development while chroma, or intensity of color, decreased. Growth decreased cladode luminosity or brightness, but some species as O. robusta ssp. larreyi did not change during development (Fig. 10). However, the hue angle values were similar among species and production system, which may indicates that this color parameter is common among different nopalito species (Calvo-Arriaga et al., 2010). In this study, none of the species displayed the color attributes considered as indicator of high quality, which had a hue angle near $114^{\circ}$ and a chroma and luminosity of 30 and 43, respectively (George et al., 2004). In addition, presence of waxy cuticle and pubescence in species as O. robusta ssp. larreyi and $O$. undulata $\times$ O. tomentosa may influence the chroma and lightness values and their acceptababilty by consumers.

The bending and penetrating resistance and mucilage content of sprouts in the four species studied were lower than those registered on harvested in commercial plantations (Table 6). These differences may be due to a continuous water supply and the protective environment of greenhouse. The high bending and penetration resistance forces in nopalitos produced on soil is explained by the fact that, under those conditions, fibers are more robust than those of nopalitos grown in a hydroponic system in a protective greenhouse environment (RodríguezFelix \& Villegas-Ochoa, 1997). Moreover, the lower mucilage content in nopalitos species produced under hydroponic system can be explained by the absence of temperature oscillations and water stress than in an open production systems on soil. Some authors had documented an increase in mucilage production in plants under stress conditions (GarcíaRuíz, 2007; Goldstein \& Nobel, 1991, 1994; Nobel et al., 1992) because the mucilage has an important role on water storage, freeze tolerance, calcium metabolism, and as reserve of carbohydrates. Nopalitos produced under hydroponics system had a lower mucilage higher content due to plenty water availability and to the protective greenhouse environment, thus the dissimilarity observed may be due to genetic differences among species. 

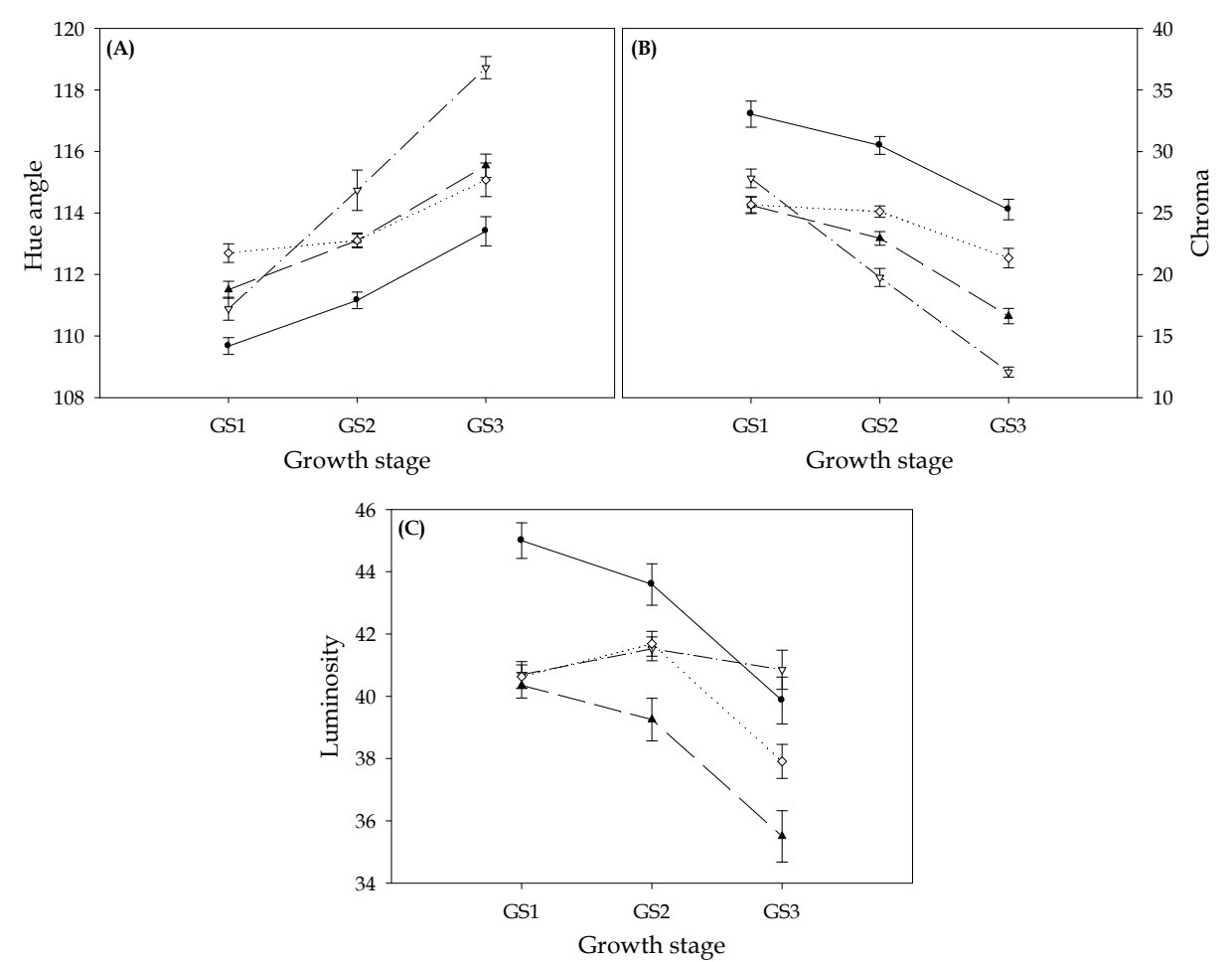

Fig. 10. Color parameters as hue angle (a) chroma or intensity of color (b) and luminosity (c) in four species at three growth stages produced in hydroponics system. $(\bullet) N$. cochenillifera,

$(\Delta)$ O. ficus-indica, $(\nabla)$ O. robusta ssp. larreyi and $(\diamond)$ O. tomentosa $\times$ O. undulata (LópezPalacios et al., 2010).

Nopalitos grown on hydroponics had similar $\mathrm{pH}$ values than nopalitos grown on soil (Table 7). This similarity is probably due to that in the field these plants follow the same trend observed on hydroponics system to produce new cladodes. Moreover, the acidity changes as a reaction to environmental conditions also are related to changes in mucilage viscosity (Trachtemberg \& Mayer, 1981), which permit to the plant tolerate different stress conditions. Also, none of the nopalitos species produced under hydroponics had similar values in the three color parameters to those produced on soil (Table 7). Razo \& Sánchez (2002) observed in nopalitos produced on soil differences in color parameters during the day. They associated these changes to modification of pigments; nevertheless, the color of nopalitos also depends on the production system as observe in O. ficus-indica (Table 7).

Nopalito quality is determinated by a set of anatomical and physiological features that result in perceptible attributes which allow the consumer to develop certain preferences for the various nopalito species available in a particular region (Cantwell, 1995; Figueroa, 1984; López-Palacios et al., 2010). Thus, the yield from nopalitos of different species produced under hydroponics system is an opportunity to supply a market with different preferences. The results obtained in the present study mar serve for future studies on hydroponics nopalito production and their marketing. 


\begin{tabular}{|c|c|c|c|c|}
\hline \multirow{2}{*}{ Specie } & \multirow{2}{*}{$\begin{array}{l}\text { Production } \\
\text { system }\end{array}$} & \multicolumn{2}{|c|}{ Resistance to } & \multirow{2}{*}{$\begin{array}{c}\text { Mucilage content } \\
(\%) \\
\end{array}$} \\
\hline & & Flexion $(\mathrm{N})$ & Penetration $(\mathrm{N})$ & \\
\hline N. cochenillifera a & Soil & -- & --- & 15.9 \\
\hline N. cochenillifera ${ }^{\mathrm{b}}$ & Hydroponics & 4.85 & 2.77 & 8.27 \\
\hline O. albicarpac & Soil & --- & --- & 6.89 \\
\hline O. ficus-indica ${ }^{\mathrm{b}}$ & Hydroponics & 7.21 & 2.91 & 5.34 \\
\hline O. ficus-indica ${ }^{\mathrm{c}}$ & Soil & --- & --- & 11.72 \\
\hline O. ficus-indica d & Soil & --- & --- & $6.90-8.57$ \\
\hline O. ficus-indica $\mathrm{e}$ & Soil & $21.8-30.0$ & $11.0-15.0$ & --- \\
\hline O. ficus-indica $^{\mathrm{f}}$ & Soil & --- & 19.0 & --- \\
\hline O. hyptiacantha ${ }^{\mathrm{c}}$ & Soil & --- & --- & 8.47 \\
\hline O. megacantha ${ }^{\mathrm{c}}$ & Soil & --- & --- & 7.40 \\
\hline O. robusta ssp. larreyi b & Hydroponics & 7.95 & 2.39 & 6.76 \\
\hline O. streptacanthac & Soil & --- & --- & 7.18 \\
\hline O. undulata $\times$ O. tomentos ${ }^{\mathrm{b}}$ & Hydroponics & 3.45 & 2.52 & 6.93 \\
\hline
\end{tabular}

a Nerd et al., 1997

b, c López-Palacios et al., 2010, 2011

d Peña-Valdivia \& Sánchez-Urdaneta, 2006

e Rodríguez-Félix \& Villegas-Ochoa, 1997

${ }^{\mathrm{f}}$ Guevara et al., 2003

Table 6. Resistance to the flexion and penetration forces, and mucilage content of nopalitos produced on commercial soil plantations and hydroponic system.

\begin{tabular}{|c|c|c|c|c|c|}
\hline \multirow{2}{*}{ Species } & \multirow{2}{*}{$\begin{array}{l}\text { Production } \\
\text { system }\end{array}$} & \multicolumn{3}{|c|}{ Color } & \multirow{2}{*}{$\mathrm{pH}$} \\
\hline & & Hue angle & Chroma & Luminosity & \\
\hline N. cochenillifera a & Soil & --- & --- & --- & 4.4 \\
\hline N. cochenillifera $\mathrm{b}$ & Hydroponics & 111.14 & 30.18 & 43.20 & 4.8 \\
\hline O. ficus-indica ${ }^{\mathrm{b}}$ & Hydroponics & 112.90 & 20.46 & 38.96 & 4.5 \\
\hline O. ficus-indica ${ }^{c}$ & Soil & 117.66 & 16.60 & --- & --- \\
\hline O. ficus-indica $\mathrm{d}$ & Soil & $116.0-120.0$ & $17.0-21.0$ & $40.0-49.0$ & --- \\
\hline O. ficus-indica e & Soil & --- & --- & --- & $4.0-6.0$ \\
\hline O. ficus-indica ${ }^{\mathrm{f}}$ & Soil & 114.0 & 29.37 & 43.03 & --- \\
\hline O. megacantha d & Soil & --- & -- & --- & $5.0-6.0$ \\
\hline O. robusta ssp. larreyi b & Hydroponics & 114.15 & 21.13 & 41.05 & 4.6 \\
\hline $\begin{array}{l}\text { O. undulata } \times O \text {. } \\
\text { tomentosa } \mathrm{b}\end{array}$ & Hydroponics & 113.51 & 24.26 & 40.20 & 4.5 \\
\hline
\end{tabular}

a Ochoa et al., 2004

b López-Palacios et al., 2010

c Anzures-Santos et al., 2004

d Calvo-Arriaga et al., 2010

e Flores-Hernández et al., 2004

${ }^{f}$ George et al., 2004

Table 7. Color attributes and acidity $(\mathrm{pH})$ of nopalitos produced on commercial soil plantations and hydroponic system. 


\section{Conclusion and future research}

Production of cactus pear cladodes in hydroponics represents an opportunity for producing biomass in arid and semiarid regions. Productivity of this system, harvesting nopalito or fodder, overcomes that of soil systems. Besides, quality of sprouts as nopalito or fodder is comparable or better than that recorded on traditional production systems. Nevertheless, establishment of hydroponics require high initial investment. However, economic evaluations of these systems are not documented. In addition, due to the possibility for recycling the water, hydroponics is considered an efficient water use system. Last, arguments that support some investigations and treatise on cactus pear hydroponics, still need to be evaluated and verified.

\section{Acknowledgment}

This research was conducted with the initial economic support from the Research Support Fund of the Universidad Autónoma de San Luis Potosí through grant CO4-FAI, 04-37.37, and afterwards from the National Commission of Arid Zones and the Fundación Produce San Luis Potosí, A.C. The "Luchadores de San José de la Peña" group of local farmers, assisted in the investigation and provided access to their infrastructure. The first author was awarded CONACYT's scholarship No. 181453 for undertaking his M. Sc. Program. The second author thanks for the scholarship CO6-PIFI-11.27.48 granted by the Science Inmersion Program of the Universidad Autónoma de San Luis Potosí.

\section{References}

Anaya P., M. A. (2001). History of the use of Opuntia as forage in México. In: Cactus (Opuntia spp.) as forage, Mondragón-Jacobo, C. \& Pérez-González, S. (Eds), 3-12, Food and Agriculture Organization of the United Nations, ISBN 92-5-104705-7, Rome, Italy.

Anzures-Santos, G., Corrales-García, J. \& Peña-Valdivia, C.B. (2004). Efecto el almacenamiento en algunos atributos de calidad del nopalito desespinado (Opuntia sp.) en la variante Atlixco. In: Memoria del X Congreso Nacional, VIII Internacional sobre el Conocimiento y Aprovechamiento del Nopal y otras Cactaceas de Valor Económico $y$ del Fifth International Congress on Cactus Pear and Cochineal (CD Edition), Flores V., C. (Ed.), Universidad Autónoma Chapingo, Fondo de las Naciones Unidas para la Alimentación y la Agricultura and International Society for Horticultural Science. Chapingo, México.

Betancourt-Domínguez, M.A., Hernández-Pérez, T., García-Saucedo, P., Cruz-Hernández, A. \& Paredez-López, O. (2006). Physico-chemical changes in cladodes (nopalitos) from cultivated and wild cacti (Opuntia spp.). Plant Foods for Human Nutrition, Vol. 61, No. 3, (September 2006), 115-119, ISSN 0921-9668.

Blanco-Macías, F.R., Valdez-Cepeda, R.D., Ruiz-Garduño, R. \& Márquez-Madrid, M. (2004). Producción intensiva de nopalito orgánico durante cuatro años en Zacatecas, In: Memoria el X Congreso Nacional y VII Congreso Internacional sobre Conocimiento y Aprovechamiento del Nopal y del Fifth International Congress on Cactus Pear, Flores V., C.A. (Ed.), 2, Chapingo, México.

Cantwell, M. (1992). Aspectos de calidad y manejo postcosecha de nopalitos, In: Conocimiento y Aprovechamiento del Nopal. V Congreso Nacional y III Internacional. 
Memoria de Resúmenes, Salazar, S. \& López, D. (Eds.), 110, Universidad Autónoma Chapingo, Chapingo, México.

Calderón, P. N., Estrada L., A. A. \& Martínez A., J. L. (1997). Efecto de la salinidad en el crecimiento y absorción nutrimental de plantas micropropagadas de nopal (Opuntia spp.). In: Memoria del Séptimo Congreso Nacional y Quinto Internacional sobre el Conocimiento y Aprovechamiento del Nopal, Vázquez A., R.E. (Ed.), 165-166, Monterrey, México.

Calvo-Arriaga, A.O., Hernández-Montes, A., Peña-Valdivia, C.B., Corrales-García, J. \& Aguirre-Mandujano, E. (2010). Preference mapping and rheological properties of four nopal (Opuntia spp.) cultivars. Journal of the Profesional Assoiation for Cactus Development, Vol. 12, 127-142, ISSN 1938-6648.

Collins, M. \& Fritz, J.O. (2003). Forage quality, In: Forages, Barnes, R.F., Nelson, C.J., Collins, M. \& Moore, J.K. (Eds.), 363-390, Iowa State Press, Ames, Iowa, USA.

Contreras-Padilla, M., Pérez-Torrero, E., Hernández-Urbiola, M.I., Hernández-Quevedo, G., del Real, A., Rivera-Muñoz, E.M. \& Rodríguez-García, M.E. (2011). Evaluation of oxalates and calcium in nopal pads (Opuntia ficus-indica var. redonda) at different madurity stages, Journal of Food Composition and Analysis, Vol. 24, No. 1, (February 2011), 38-43, ISSN 0889-1575.

Cordeiro dos S., D., M. de Andrade L., F., Marcos D., I., Farias, M.V. \& Ferreira dos S., V.F. (2000), Productividade de cultivares de palma forrageira (Opuntia e Nopalea), In: II Congresso Nordestino de Produção Animal y VII Simposio Nordestino de Alimentação de Ruminantes, 121-123, Teresina, Brasil.

Cordeiro dos S., D., Lira, M.A., Farias, I., Dias, F.M., Silva, F.G. (2004). Competition of forage cactus varieties under semi-arid conditions in the northeast of Brazil. In: Memoria del X Congreso Nacional y VII Congreso Internacional sobre Conocimiento y Aprovechamiento del Nopal y del Fifth International Congress on Cactus Pear and Cochineal (CD Edition), Universidad Autónoma Chapingo, Food and Agriculture Organization e International Society for Horticultural Science, Chapingo, México.

Cushman, J.C. (2001). Crassulacean acid metabolism. A plastic photosynthetic adaptation to arid environments, Plant Physiology, Vol. 127, No. 4, (December 2001), 1439-1448, ISSN 0032-0839.

De Alba, J. (1971). Alimentación del ganado en América Latina (2nd. Edition), La Prensa Médica Mexicana, México, D.F.

Figueroa H., F. (1984). Estudio de las nopaleras cultivadas y silvestres sujetas a recolección para el mercado en el Altiplano Potosino-Zacatecano, Tesis Profesional, Escuela de Agronomía, Universidad Autónoma de San Luis Potosí, San Luis Potosí, México.

Flores V., C.A. \& Aguirre R., J.R. (1979). El nopal como forraje. Universidad Autónoma Chapingo, Chapingo, México, $80 \mathrm{p}$.

Flores V., C.A. \& Olvera, J. (1994). El sistema-producto nopal verdura en México, Universidad Autónoma Chapingo, Texcoco, México.

Flores-Hernández A., Orona-Castillo I., Murillo-Amador B., Valdez-Cepeda R.D. \& GarcíaHernández J.L. (2004). Producción y calidad de nopalito en la región de la comarca lagunera de México y su relación con el precio en el mercado nacional. Journal of the Profesional Assoiation for Cactus Development, Vol. 6, 23-34, ISSN 1938-6648. 
Gallegos-Vázquez, C., Olivares-Sáenz, E., Vázquez-Alvarado, R. \& Zavala-García, F. (2000). Absorción de nitrato y amonio por plantas de nopal en hidroponía. Terra, Vol. 18, 133-139, ISSN 1870-9982.

Gárate, A. \& Bonilla, I. (2000). Nutrición mineral y producción vegetal. In: Fundamentos de Fisiología Vegetal, Azcón, B.J. \& Talón, M. (Eds.), 113-130, Mc Graw Hill, ISBN 9788448151683, Madrid, España.

García de Cortázar, V. \& Nobel, P.S. (1992). Biomass and fruit production for the prikly pear cactus, Opuntia ficus-indica. Journal of the American Society for Horticultural Science, Vol. 117, No. 4, (July 1992), 558-562, ISSN 0003-1062.

García, E. (2004). Modificaciones al sistema de clasificación climática de Köppen (5th edition), Universidad Nacional Autónoma de México, México, DF.

García H., E. \& Peña V., C. (1995). La pared celular. Componente fundamental de las células vegetales, Universidad Autónoma Chapingo, Chapingo, ISBN 9688843342, Estado de México, México.

García-Ruíz, M.T. (2007). Procesos fisiológicos y contenido de polisacáridos estructurales en nopalito (Opuntia spp.) y su modificación por el potencial de agua del suelo, Tesis para obtener el grado de Maestro en Ciencias, Colegio de Postgraduados, Montecillo, Texcoco, Estado de México, México.

George, R.S., Corrales G., J. Peña V., C. \& Rubio H., D. (2004). Cambios en color, sabor y contenido de mucíalgo en noplito (Opuntia ficus-indica) escaldado con tequezquite. In: Memoria del X Congreso Nacional, VIII Internacional sobre el Conocimiento y Aprovechamiento del Nopal y otras Cactaceas de Valor Económico y del Fifth International Congress on Cactus Pear and Cochineal (CD Edition), Flores V., C. (Ed.), Universidad Autónoma Chapingo, Fondo de las Naciones Unidas para la Alimentación y la Agricultura and International Society for Horticultural Science. Chapingo, México.

Gibson, A.C. \& Nobel, P.S. (1986). The cactus primer, Harvard University Press, ISBN 9780674089914, Cambrige, Massachusets, USA.

Gonzaga de A., S. \& Cordeiro dos S., D. (2005). Palma forrageira. In: Espécies vegetais exóticas com potencialidades para semi-árido brasilero, Piedade, L. H. \& Assis M., E. (Eds), 91127, Empresa Brasileira de Pesquisa Agropecuária, ISBN 8573832878, Brasilia, Brasil.

Goldstein, G.; Nobel, P.S. 1991. Changes in osmotic pressure and mucilage during lowtemperature acclimation of Opuntia ficus-indica, Plant Physiology, Vol. 97, No. 3, (November 1991), 954-961, ISSN 0032-0889.

Goldstein, G.; Nobel, P.S. 1994. Water relations and low-temperature acclimation for cactus species varying in freezing tolerance. Plant Physiology, Vol. 104, No. 2, (February, 1994), 675-681, ISSN 0032-0889.

Gregory, R.A. \& Felker, P. (1992). Crude protein and phosphorus contents of eight contrasting Opuntia forage clones, Journal of Professional Cactus Development, Vol. 22, 323-331, ISSN 1938-6648.

Guevara, J.C., Yahia, E.M., Brito, F.E. \& Biserka, S.P. (2003). Effects of elevated concentrations of $\mathrm{CO}_{2}$ in modified atmosphere packaging on the quality of prickly pear cactus stems (Opuntia spp.), Postharvest Biology and Technology, Vol. 29, No. 2, (August 2003), 167-176, ISSN 0925-5214.

Gutiérrez O., E. \& Bernal B., H. (2004). Uso del nopal en la nutrición animal, In: Memoria del $X$ Congreso Nacional y el VII Congreso Internacional sobre Conocimiento $y$ 
Aprovechamiento del Nopal y del Fisth Intenational Congress on Cactus PEar and Cochineal. Universidad Autónoma Chapingo, Food and Agriculture Organization e International Society for Horticultural Science (CD Edition), Flores V., C (Ed). Chapingo. Mexico. Edición en DC.

López-García, J.J., Fuentes-Rodríguez, J.M. \& Rodríguez-Gámez, A. (2001). Production and use of Opuntia as forage in northern of México. In: Cactus (Opuntia spp.) as forage, Modragón-Jacobo, C. \& Pérez-González, S. (Eds), 29-36, Food and Agriculture Organization of the United Nations, ISBN 92-5-104705-7, Rome, Italy.

López-Palacios, C. (2008). Evaluación de atributos posiblemente asociados con la calidad del nopalito (Opuntia spp. y Nopalea sp.). Tesis para obtener el grado de Ingeniero, Ingeniería Agroindustrial, Facultad de Ingeniería, Universidad Autónoma de San Luis Potosí, San Luis Potosí, México.

López-Palacios, C., Peña-Valdivia, C.B., Reyes-Agüero, J.A. \& Rodríguez-Hernández, A.I. (2011). Effects of domestication on structural polysaccharides and dietary fiber in nopalitos (Opuntia spp.), Genetic Resources and Crop Evolution, DOI 10.1007/s10722011-9740-3, (Online August 2011), ISSN 0925-9864.

López-Palacios, C., Reyes-Agüero, J.A., Ramírez-Tobías, H.M., Juárez-Flores, B.I., AguirreRivera, J.R., Yañez-Espinoza, L. \& Ruíz-Cabrera, M.A. (2010). Evaluation of attributes associated with the quality of nopalito (Opuntia spp. and Nopalea sp.), Italian Journal of Food Science, Vol. 22, No., 4, 423-431, ISSN 1120-1770.

MacDougall, D.B. (2002). Colour measurement of food, In: Colour in Food: Improving quality, MacDougall, D.B. (Ed.), 33-63, Woodhead Publishing Limited, ISBN 1-85573-590-3, Cambridge, Unit Kingdom.

Mcconn, M.M. \& Nakata, P.A. (2004). Oxalate reduces calcium availability in the pads of the prickly pear cactus through formation of calcium oxalate crystals, Journal of Agricultural Food and Chemistry, Vol. 52, No. 5, (March 2004), 1371-1374, ISSN 00218561.

Mondragón-Jacobo, C, S.J. Méndez G., G. \& Olmos O. (2001). Cultivation of Opuntia for fodder production: from re-vegetation to hydroponics. In: Cactus (Opuntia spp.) as forage, Mondragón-Jacobo, C. \& Pérez-González, S. (Eds), 107-122, Food and Agriculture organization of the United States. ISBN 92-5-104705-7, Rome, Italy.

Nefzaoui, A., H. \& Ben Salem. (2001). Opuntia spp., a strategic fodder and efficient tool to combat desertification in the WANA region. In: Cactus (Opuntia spp.) as forage, Modragón-Jacobo, C. \& Pérez-González, S. (Eds), 73-90, Food and Agriculture Organization of the United Nations, ISBN 92-5-104705-7, Rome, Italy.

Nerd, A., Dumotier, M. \& Mizrahi, Y. (1997). Properties and postharvest behavior of the vegetable cactus Nopalea cochenillifera, Postharvest Biology and Technology, Vol. 10, Num. 2, (February 1997), 135- 126, ISSN 0925-5214.

Nobel, P.S. (1983). Nutrient levels in cacti-relation to nocturnal acid and growth, American Journal of Botany, Vol. 70, 1244-1253, ISSN 0002-9122.

Nobel, P.S. (1988). Environmental biology of Agaves and Cacti, Cambridge University press. ISBN 0521543347, New York, United States.

Nobel, P.S., Cavelier, J. \& Andrade, J.L. (1992). Mucilage in cacti: its apoplastic capacitance, associated solutes, and influence on tissue water relations. Journal of Experimental Botany, Vol. 43, No. 5, (May 1992), 641-648, ISSN 0022-0957. 
Ochoa, M.J., Leguizamo, G., Ayrault, G. \& Miranda, F.N. (2004). Cold storage and shelf life Nopalea cochenillifera behavior: evaluation of quality parameters. In: Memoria del X Congreso Nacional, VIII Internacional sobre el Conocimiento y Aprovechamiento del Nopal y otras Cactaceas de Valor Económico y del Fifth International Congress on Cactus Pear and Cochineal (CD Edition), Flores V., C. (Ed.), Universidad Autónoma Chapingo, Fondo de las Naciones Unidas para la Alimentación y la Agricultura and International Society for Horticultural Science. Chapingo, México.

Odum, E.P. (1972). Ecología (3rd Edition), Interamericana, México, D.F.

Olmos O., G., Méndez G., S. de J. \& Martínez H., J. (1999). Evaluación de 29 cultivares de nopal para producción de forraje en hidroponía. In: Memoria del Octavo Congreso Nacional y Sexto Congreso Internacional Sobre Conocimiento y Aprovechamiento del Nopal, Aguirre R., J. R. \& Reyes A., J. A. (eds), 105-106, San Luis Potosí, México.

Paiz, R.C., Juárez F., B.I., Aguirre R., J.R., Cárdenas O., N.C., Reyes-Agüero, J.A., García C., E. \& Álvarez F., G. (2010). Glucose-lowering effect of xoconostle (Opuntia joconostle A. Web., Cactaceae) in diabetic rats. Journal of Medicinal Plants Research, Vol. 4, No. 22, (November 2010), 2326-2333, ISSN 1996-0875.

Peña-Valdivia, C.B. \& Sánchez-Urdaneta, B.A. (2006). Nopalito and cactus pear (Opuntia spp.) polysaccharides: mucilage and pectin. Acta Horticulturae, Vol. 728, No. 1, (December 2006), 241-248, ISSN 0567-7572.

Pimienta-Barrios, E., Zañudo-Hernández, J., Rosas-Espinosa, V.C., Vañenzuela-Tapia, A. \& Nobel, P.S. (2005). Young daughter cladodes affect $\mathrm{CO}_{2}$ uptake by mother cladodes of Opuntia ficus-indica, Annals of Botany, Vol. 95, No. 2, (January 2005), 363-369, ISSN 0305-7364.

Pinos-Rodríguez, J.M., Duque B., R, Reyes-Agüero, J.A., Aguirre-Rivera, J.R. \& González, S.S. (2003). Contenido de nutrientes en tres especies de nopal forrajero. In: Memoria del IX Congreso Nacional y VII Congreso Internacional sobre Conocimiento y Aprovechamiento del Nopal, Esparza F., G., Salas, M.A., Mena C., J. \& Valdez C., R.D. (Eds.), 60-63, Universidad Autónoma Chapingo, Universidad Autónoma de Zacatecas e Instituto Nacional de Investigaciones Forestales Agrícolas y Pecuarias. Zacatecas, México.

Pinos-Rodríguez, J.M., Duque B., R., Reyes-Agüero, J.A., Aguirre-Rivera, J.R., García-López, J.C. \& González-Muñoz, S. (2006). Effect of species and age on nutrient content and in vitro digestibility of Opuntia spp., Journal of Applied animal research, Vol. 30, 13-17, ISSN 0971-2119.

Ramírez-Tobías, H.M. (2006). Productividad primaria y calidad nutrimental de nopal (Opuntia spp. y Nopalea sp.) en condiciones intensivas, Tesis para obtener el grado de Maestro en Ciencias, Programa Multidisciplinario de Posgrado en Ciencias Ambientales, Universidad Autónoma de San Luis Potosí, México.

Ramírez-Tobías, H.M., Aguirre-Rivera, J.R., Pinos-Rodríguez, J.M. \& Reyes-Agüero, J.A. (2010). Nopalito and forage productivity of Opuntia spp. and Nopalea sp. (Cactaceae) growing under greenhouse hydroponics system, Journal of Food, Agriculture E Environment, Vol. 8, No. 3 \& 4, (July-October 2010), 660-665, ISSN 1459-0255.

Ramírez-Tobías, H.M., Reyes-Agüero, J.A., Pinos-Rodríguez, J.M. \& Aguirre R., J.R. (2007a). Effect of the species and maturity over the nutrient content of cactus pear cladodes. Agrociencia, Vol. 41, No. 6, (August 2007), 619-626, ISSN 1405-3195. 
Ramírez-Tobías, H.M., Reyes-Agüero, J.A., Aguirre R., J.R. (2007b). Construcción, establecimiento y manejo de un módulo hidropónico para producir nopal, UASLPFundación produce San Luis Potosí, AC-CONAZA, ISBN 970-705-069-1, San Luis Potosí, S.L.P. México.

Razo M., Y. \& Sánchez H., M. (2002). Acidez de 10 variantes de nopalito (Opuntia spp.) y su efecto en las propiedades químicas y sensoriales, Tesis de Licenciatura, Departamento de Ingeniería Agroindustrial, Universidad Autónoma Chapingo, México.

Rodríguez-Félix A. \& Cantwell M. (1988). Developmental changes in composition and quality of prickly pear cactus cladodes (nopalitos). Plant Foods for Human Nutrition, Vol. 38, No. 1, (March 1988), 83-93, ISSN 0921-9668.

Rodríguez-Felix, A. \& Villegas-Ochoa, M.A. (1997). Quality of cactus stems (Opuntia ficusindica) during low-temperature storage. Journal of Professional Cactus Development, Vol. 2, 142-152, ISSN 1938-6648.

Rodríguez-García, M.E., de Lira, C., Hernández-Becerra, E., Cornejo-Villegas, M.A., Palacios-Fonseca, A.J., Rojas-Molina, I., Reynoso, R., Quintero, L.C. Del Real, A., Zepeda, T.A. \& Muñoz-Torres, C. (2008). Physicochemical characterization of nopal pads (Opuntia ficus-indica) and dry vacuum nopal powders as a function of the maturation, Plant Foods for Human Nutrition, Vol. 62, No. 3, (September 2008), 107112, ISSN 0921-9668.

Sáenz, C. (2000). Processing technologies: An alternative for cactus pear (Opuntia spp.) fruits and cladodes, Journal of Arid Environments, Vol. 46, No. 3, (November 2000), 209225, ISSN 0140-1963.

Sáenz, C., Sepúlveda, E. \& Matsuhiro, B. (2004). Opuntia spp. mucilage's: A functional component with industrial perspectives. Journal of Arid Environments, Vol. 57, No. 2, (July 2004), 275-290, ISSN 0140-1963.

Sánchez del C., F. \& Escalante R., E. R. (1983). Hidroponía, Universidad Autónoma Chapingo, Chapingo, México.

Sánchez del C., F. \& Escalante R., E.R. (1988). Hidroponía (3rd. Edition), Universidad Autónoma Chapingo, Chapingo, Estado de México, México.

Sánchez-Venegas, G. (1995). Estimación del área fotosintética caulinar de Nopalea cochenillifera (L.) Salm-Dick. In: Memoria del VI Congreso Nacional y IV Congreso Internacional sobre Conocimiento y Aprovechamiento del Nopal. Pimienta B., E., Neri L., C., Muñoz U., A. \& Huerta, M. (Eds.), 103-106, Universidad de Guadalajara, Guadalajara, Jalisco, México.

SAS, (1990). User's Guide: Statistics. SAS Inst. Inc., Cary, North Caroline, USA.

Stintzing F.C. \& Carle, R. (2005). Cactus stems (Opuntia spp.): A review on their chemistry, technology, and uses. Molecular Nutrition \& Food Research, Vol. 49, No. 2, (February 2005), 175-194, ISSN 1613-4133.

Tegegnea, F., Kijorab, C. \& Petersb, K.J. (2007). Study on the optimal level of cactus pear (Opuntia ficus-indica) supplementation to sheep and its contribution as source of water. Small Ruminant Research, Vol. 72, No. 2-3, (October 2007), 157-164, ISSN 09214488.

Trachtenberg, S. \& Mayer, A.M. (1981). Composition and properties of Opuntia ficus-indica mucilage, Phytochemistry, Vol. 20, No. 12, (December 1981), 2665-2668, ISSN 00319422. 
Van Soest, P., Robertson, J. \& Lewis, B. (1991). Methods for dietary fiber, neutral detergent fiber, and nonstarch polysaccharides in relation to animal nutrition, Journal of Dairy Science, Vol. 75, No. 10, (October 1991), 3583-3597, ISSN 0022-0302. 


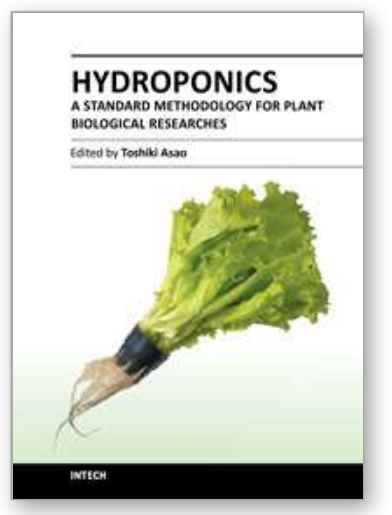

\section{Hydroponics - A Standard Methodology for Plant Biological Researches}

Edited by Dr. Toshiki Asao

ISBN 978-953-51-0386-8

Hard cover, 244 pages

Publisher InTech

Published online 23, March, 2012

Published in print edition March, 2012

Hydroponics-A standard methodology for plant biological researches provides useful information on the requirements and techniques needs to be considered in order to grow crops successfully in hydroponics. The main focuses of this book are preparation of hydroponic nutrient solution, use of this technique for studying biological aspects and environmental controls, and production of vegetables and ornamentals hydroponically. The first chapter of this book takes a general description of nutrient solution used for hydroponics followed by an outline of in vitro hydroponic culture system for vegetables. Detailed descriptions on use of hydroponics in the context of scientific research into plants responses and tolerance to abiotic stresses and on the problems associated with the reuse of culture solution and means to overcome it are included. Some chapters provides information on the role of hydroponic technique in studying plant-microbe-environment interaction and in various aspects of plant biological research, and also understanding of root uptake of nutrients and thereof role of hydroponics in environmental clean-up of toxic and polluting agents. The last two chapters outlined the hydroponic production of cactus and fruit tree seedlings. Leading research works from around the world are brought together in this book to produce a valuable source of reference for teachers, researcher, and advanced students of biological science and crop production.

\section{How to reference}

In order to correctly reference this scholarly work, feel free to copy and paste the following:

Hugo Magdaleno Ramírez-Tobías, Cristian López-Palacios, Juan Rogelio Aguirre-Rivera and Juan Antonio Reyes-Agüero (2012). Hydroponic Cactus Pear Production, Productivity and Quality of Nopalito and Fodder, Hydroponics - A Standard Methodology for Plant Biological Researches, Dr. Toshiki Asao (Ed.), ISBN: 978953-51-0386-8, InTech, Available from: http://www.intechopen.com/books/hydroponics-a-standardmethodology-for-plant-biological-researches/hydroponic-cactus-pear-production-productivity-and-quality-ofnopalito-and-fodder

\section{INTECH}

open science | open minds

\section{InTech Europe}

University Campus STeP Ri

Slavka Krautzeka 83/A

51000 Rijeka, Croatia

Phone: +385 (51) 770447

\section{InTech China}

Unit 405, Office Block, Hotel Equatorial Shanghai

No.65, Yan An Road (West), Shanghai, 200040, China

中国上海市延安西路65号上海国际贵都大饭店办公楼 405 单元

Phone: +86-21-62489820 
Fax: +385 (51) 686166

Fax: +86-21-62489821

www.intechopen.com 
(C) 2012 The Author(s). Licensee IntechOpen. This is an open access article distributed under the terms of the Creative Commons Attribution 3.0 License, which permits unrestricted use, distribution, and reproduction in any medium, provided the original work is properly cited. 